\title{
FIRST TRIMESTER PRENATAL DIAGNOSIS OF HAEMOPHILIA A USING FACTOR VIII GENE PROBE
}

\author{
Akira Yoshioka, ${ }^{1}$ Hiroyuki NaKa, ${ }^{1}$ Takuya Nishimura, ${ }^{1}$ \\ Kuninori Kuze, ${ }^{1}$ Ichiro TanaKa, ${ }^{1}$ Sadaaki Mikami, ${ }^{2}$ \\ Masahiko Matsumoto, ${ }^{3}$ Keiichiro Yoshioka, ${ }^{4}$ and Hiromu Fukui ${ }^{1}$ \\ ${ }^{1}$ Department of Paediatrics, Nara Medical College, \\ Kashihara, Nara 634, Japan \\ Paediatric Clinic, National Nara Hospital, \\ Nara 630, Japan \\ ${ }^{3}$ Obstetrical and Gynaecological Clinic, Osaka Municipal Perinatal Centre, \\ Osaka 557, Japan \\ ${ }^{4}$ Paediatric Clinic, National Osaka Hospital, \\ Osaka 540, Japan
}

\begin{abstract}
Summary Accurate first-trimester prenatal diagnosis was achieved in a Japanese haemophilia A family by the use of a restriction fragment length polymorphism (RFLP) located within the F.VIII gene. Since the pregnant woman's heterozygosity for BclI polymorphism in F.VIII/intron 18 (F8A) probe was informative, chorionic villus sampling (CVS) was performed at 9 weeks of gestation. Restriction analysis showed that the fetus was heterozygous for the $B c l \mathrm{I}$ site and had received a normal paternal X chromosome $(0.9 \mathrm{~kb})$ and a normal maternal $X(1.2 \mathrm{~kb})$. Therefore, we concluded that the fetus was a non-carrier female. Pregnancy went to term and woman gave birth to an apparently healthy female. At one week after birth a coagulation study confirmed that the newborn infant is not a carrier. The first-trimester prenatal diagnosis of haemophilia A is possible by CVS due to a RFLP in the F.VIII gene.
\end{abstract}

Key Words haemophilia A, prenatal diagnosis, restriction fragment length polymorphism (RFLP), factor VIII gene, chorionic villus sampling (CVS)

\section{INTRODUCTION}

Until recently prenatal diagnosis of haemophilia $\mathrm{A}$ has been carried out by conventional measurement of factor VIII procoagulant activity (F.VIII:C) as well

Received April 13, 1989; Accepted May 8, 1989 
as antigen (F.VIII:Ag) of fetal plasma between the 18th and 21 st weeks of gestation (Mibashan et al., 1979; Firshein et al., 1979). This type of prenatal diagnosis in the second trimester may associate with a risk of fetal mortality and lead to late termination of pregnancy in affected cases.

A new technique for sampling fetal tissue by chorionic villus sampling (CVS) at 8-11 weeks' gestation has circumvented these problems (Williamson et al., 1981). In addition, the introduction of analysis of DNA polymorphic markers genetically linked to the haemophilic locus has greatly improved the accuracy of diagnosis (Gitschier et al., 1985a; Antonarakis et al., 1985). Here we describe the first case of prenatal diagnosis of Japanese haemophilia A by the use of a restriction fragment length polymorphism (RFLP) located within the factor VIII gene.

\section{MATERIALS AND METHODS}

Assays of factor VIII (F.VIII). Factor VIII clotting activity (F.VIII:C) was assayed as kaolin-activated partial thromboplastin time (K-PTT) (Hardisty and MacPherson, 1962) in immuno-depleted F.VIII deficient plasma. A two-site solid phase immunoradiometric assay (IRMA) for F.VIII:Ag was performed using hightitre alloantibodies derived from a patient with haemophilia A (Yoshioka et al., 1983). Laurell's electroimmunoassay (EIA) for von Willebrand factor antigen (vWF:Ag) was performed using a rabbit antibody (Fukui et al., 1977). Normal pooled-plasma obtained from 10 donors was used as control material. One unit is the amount of F.VIII or VWF in $1 \mathrm{ml}$ of normal pooled-plasma.

Analysis of RFLPs. High molecular weight genomic DNA was isolated from leukocytes in 10-20 $\mathrm{ml}$ of citrated peripheral blood as described previously (Nishino et al., 1986).

Chorionic villus samples obtained by the transcervical route under ultrasound guidance. Aspiration biopsy was carried out with a Portex catheter. The sample was checked microscopically to exclude contamination by maternal decidua before incubation at $56^{\circ} \mathrm{C}$ for $3 \mathrm{hr}$ in $250 \mu \mathrm{l} 0.075 \mathrm{M}$ sodium dodecylsulphate, and $10 \mu \mathrm{l}$ proteinase $\mathrm{K}$. This was followed by DNA extractions with phenol and chloroform. The genomic DNA isolated from both peripheral leukocytes and chorionic villi was digested with $B c l$ I restriction endonuclease (Toyobo, Japan) under conditions recommended by the supplier. The methods of precipitation of DNA, gel electrophoresis, Southern blotting, hybridization of restriction fragments with the ${ }^{32} \mathrm{P}$ labeled F.VIII probe, washing of filters and autoradiography have been described previously (Mikami et al., 1987; Nishino et al., 1987).

F.VIII gene probe. The restriction enzyme BclI detects a common polymorphism that lies $3^{\prime}$ of exon 18 in the F.VIII gene. Using this enzyme and a 647 base pair (bp) StuI/ScaI genomic probe, Factor VIII/intron 18 (F8A, provided by Dr. R.M. Lawn, Genentech Inc., Calif.) (Gitschier et al., 1985b), a restriction fragment of variable length, $879 \mathrm{bp}$ or $1,165 \mathrm{bp}$, can be detected (Fig. 1). 


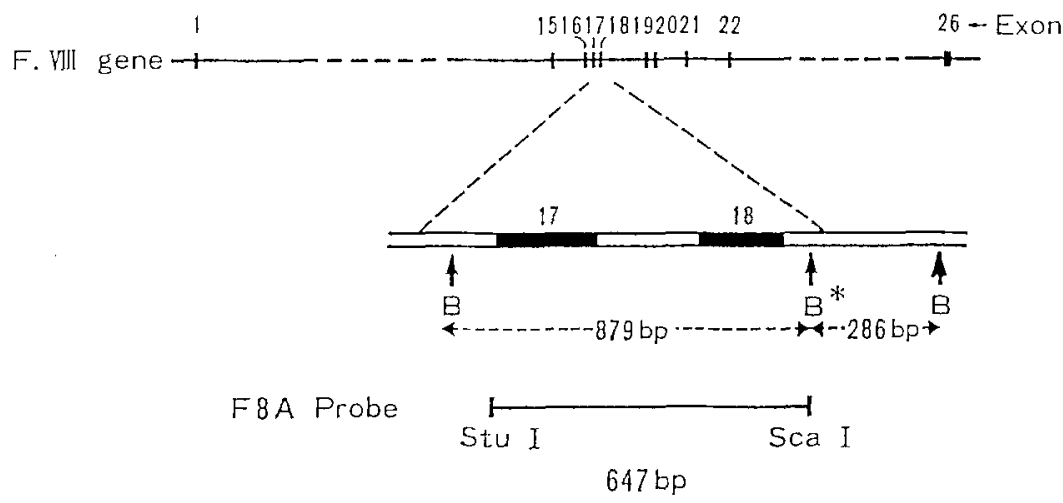

Fig.1. Position of $B c l$ I polymorphism within factor VIII gene (Gitschier et al., 1985b). $B^{*}$, polymorphic site.

Table 1. Factor VIII/von Willebrand factor in the family members.

\begin{tabular}{lccc}
\hline & $\begin{array}{c}\text { F.VIII:C } \\
(\mathrm{u} / \mathrm{d})\end{array}$ & $\begin{array}{c}\text { F.VIII:Ag } \\
(\mathrm{u} / \mathrm{dl})\end{array}$ & $\begin{array}{c}\text { vWF:Ag } \\
(\mathrm{u} / \mathrm{dl})\end{array}$ \\
\hline Propositus (Haemophilia A) & $<1$ & $<0.1$ & 80 \\
Father of the propositus & N.D. & N.D. & N.D. \\
Mother of the propositus at non-pregnant state & 38 & 49 & 105 \\
Neonate at 1 week after birth & 105 & 112 & 90 \\
\hline
\end{tabular}

N.D., not determined. Normal range of F.VIII:C, F.VIII:Ag and vWF:Ag in normal subjects is $50-200 \mathrm{u} / \mathrm{dl}$.

Fetal sexing. Fetal sexing was performed by karyotyping of the cultured chorionic villi according to standard protocols.

Subjects. The propositus, a 6-year-old boy, had manifested easy bruising and joint bleeding since infancy. He had a recurrent ankle joint hemorrhage at the age of 1 , when a diagnosis of severe haemophilia A (F.VIII:C $<1$ u/dl, F.VIII: $\mathrm{Ag}<0.1 \mathrm{u} / \mathrm{dl}$ ) was made at Osaka National Hospital. At the same time the 29year-old mother of the propositus was considered to be a haemophilia A carrier on the basis of low plasma levels of F.VIII:C (38 u/dl) and F.VIII:Ag (49 u/dl), and normal levels of vWF:Ag $(105 \mathrm{u} / \mathrm{dl})$ (Table 1).

Unwilling to bear a second haemophilic son, she visited our Paediatric Department for prenatal diagnosis of the fetus of her second pregnancy. After obtaining informed consent, we examined, using the F8A probe (Factor VIII/intron 18), the BclI RFLP of the F.VIII gene in the pregnant woman, her husband and the propositus. Subsequently, chorionic villus sampling was performed at 9 weeks of gestation, followed by analysis of fetal DNA. 


\section{RESULTS}

No gross structural abnormalities such as a deletion directly detectable by $B c$ II RFLP analysis in the F.VIII gene were found in this family.

Analysis of the DNA from the pregnant woman (I-2) for heterozygosity at polymorphic sites within the F.VIII gene showed that she was heterozygous for the $B c l$ site in intron 18 , since $B c l$ I digestion produced $1.2 \mathrm{~kb}$ and $0.9 \mathrm{~kb}$ bands (Fig. 2). Since this woman had been diagnosed as a carrier of a haemophilia A gene and her affected son (II-1) also manifested the $B c l$ I polymorphic site, we judged that the presence of the $B c l$ I site represented by $0.9 \mathrm{~kb}$ band, marked the maternal $\mathrm{X}$ chromosome which carries the haemophilic gene. The father had the $B c l$ I site associated with the non-haemophilic gene. The $B c /$ I restriction pattern from DNA isolated from the chorionic villus showed that the fetus was heterozygous for the $B c l$ l site having both the $1.2 \mathrm{~kb}$ band from the mother and the $0.9 \mathrm{~kb}$ band from the father. On the other hand, chromosomal analysis of the chorionic villus revealed a female karyotype, $46 \mathrm{XX}$. Therefore, we concluded that the fetus was a non-carrier female.

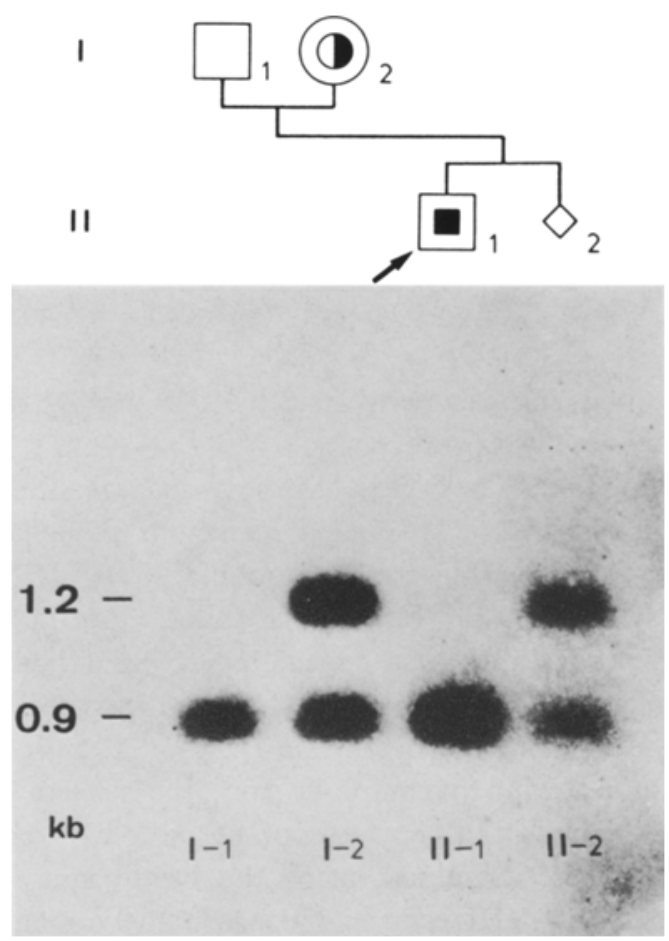

Fig. 2. Southern blots using cloned F.VIII gene probe (Factor VIII/intron 18, F8A) on samples of DNA restricted with $B c l$ I. 
The women decided to continue the pregnancy to term. At 36 weeks of gestation she gave birth to an apparently healthy female weighing 2,536 g. At 1 week after birth, the plasma level of F.VIII:C, F.VIII:Ag and vWF:Ag in the baby were $105 \mathrm{u} / \mathrm{dl}, 112 \mathrm{u} / \mathrm{dl}$ and $90 \mathrm{u} / \mathrm{dl}$, respectively (Table 1 ) and it was confirmed that she did not manifest the carrier state.

\section{DISCUSSION}

The prenatal diagnosis of haemophilia $\mathrm{A}$ based on the measurement of F.VIII in fetal blood obtained by fetoscopy is made in the second trimester (Mibashan et al., 1979; Firshein et al., 1979). Between 1985 and 1988, ten pregnancies were evaluated in our department using a new and safer procedure for fetal blood sampling: ultrasound-guided fetal liver puncture (Koresawa et al., 1987). We have recorded no sampling 'failure or spontaneous abortion so far (unpublished data). However in two other studies, the risk of spontaneous abortion after fetoscopy for the second trimester prenatal diagnosis of haemophilia $\mathrm{A}$ or for other purposes was shown to be 5.8\% (3/52) (Hoyer et al., 1985) and 6.8\% (128/1,875) (Koresawa, 1985), respectively. In addition, it was often not possible to obtain a satisfactory sample using this method (12/92) (Hoyer et al., 1985). Moreover, a major drawback of diagnosis by fetal blood sampling in the second trimester is the advanced age of the fetus at the time of diagnosis.

A new technique, linkage analysis using DNA polymorphisms should make the prenatal diagnosis of haemophilia $A$ safer and earlier. Highly informative RFLPs have been associated with several cloned DNA sequences which have been mapped within or very close to the F.VIII gene (Winter et al., 1985; Pecorara et al., 1987; Sampietro et al., 1987; Tuddenham et al., 1987).

We have already studied RFLPs to detect carriers in Japanese haemophilia A families using three intragenic DNA probes (Factor VIII/intron 18, Factor VIII/ intron 22 and Factor VIII/3' flanking) (Nishino et al., 1987; Mikami, 1988) and the extragenic DNA probe ST 14 (Nishino et al., 1987). Since the probability of recombination between the ST 14 and F.VIII gene is $4 \%$ (Gitschier, 1989), we have used the intragenic probe, Factor VIII/intron 18, in this case. Therefore, the possibility of error due to recombination between the marker $B c l$ l polymorphic site and the mutant F.VIII gene should be negligible. According to our previous data, about $27 \%$ of Japanese females are heterozygous at this locus (Mikami, 1988). Fortunately, the pregnant woman's heterozygosity for the BclI polymorphism was informative, and permitted prenatal diagnosis of subsequent offspring.

Chorionic villi sampling was successful and the karyotype identified the fetus as female. Restriction analysis showed that the fetus was heterozygous for the $B c l$ site and had received a normal paternal $X$ chromosome $(0.9 \mathrm{~kb})$ and a normal maternal $\mathrm{X}(1.2 \mathrm{~kb})$. From these results, we concluded that the fetus was not a carrier. 
The pregnancy went to term uneventfully. A coagulation study confirmed that the newborn infant is not a carrier. No abnormalities of the body surface or congenital anomalies were seen.

Prenatal diagnosis of haemophilia $\mathrm{A}$ is possible by chorionic villus sampling due to a RFLP found in the F.VIII gene. This is the first report on the first trimester prenatal diagnosis in a Japanese haemophilia A family.

Acknowledgment We wish to thank Dr. R.M. Lawn in Genentech Inc. for providing F.VIII/ intron 18 probe.

This work was supported by a Grant-in-Aid for Scientific Research (No. 63480239) from the Ministry of Education, Science and Culture of Japan.

\section{REFERENCES}

Antonarakis, S.E., Copeland, K.L., Carpenter, R.J., Jr., Carta, C.A., Hoyer, L.W., Caskey, C.T., Toole, J.J. and Kazazian, H.H., Jr. 1985. Prenatal diagnosis of haemophilia A by factor VIII gene analysis. Lancet I: 1407-1409.

Firshein, S.I., Hoyer, L.W., Lazarchick, J., Forget, B.G., Hobbins, J.C., Clyne, L.P., Pitlick, F.A., Muir, W.A., Merkatz, I.R. and Mahoney, M.J. 1979. Prenatal diagnosis of classic hemophilia. N. Engl. J. Med. 300: 937-941.

Fukui, H., Mikami, S., Okuda, T., Murashima, N., Takase, T. and Yoshioka, A. 1977. Studies of von Willebrand factor: Effects of different kinds of carbohydrate oxidases, SH-inhibitors and some other chemical reagents. Br. J. Haematol. 36: 259-270.

Gitschier, J., Lawn, R.M., Rotblat, F., Goldman, E. and Tuddenham, E.G.D. 1985a. Antenatal diagnosis and carrier detection of haemophilia A using factor VIII gene probe. Lancet I: 1093-1094.

Gitschier, J., Drayna, D., Tuddenham, E.G.D., White, R.L. and Lawn, R.M. 1985b. Genetic mapping and diagnosis of haemophilia $\mathrm{A}$ achieved through a $B c l$ polymorphism in the factor VIII gene. Nature 314: 738-740.

Gitschier, J. 1989. The molecular genetics of hemophilia A. In Coagulation and Bleeding Disorders. The Role of Factor VIII and von Willebrand Factor, Zimmerman, T.S. and Ruggeri, Z.M., eds., Marcel Dekker, Inc., New York and Basal, pp. 23-46.

Hardisty, R.M. and MacPherson, J.C. 1962. A one stage factor VIII (anti-haemophilic globulin) assay and its use on venous and capillary plasma. Thrombos. Diathes Haemorrh. 34: 869872.

Hoyer, L.W., Carta, C.A., Golbus, M.S., Hobbins, J.C. and Mahoney, M.J. 1985. Prenatal diagnosis of classic hemophilia (hemophilia A) by immunoradiometric assay. Blood 65: 13121317.

Koresawa, M. 1985. Prenatal diagnosis and fetal therapy utilizing fetoscope. Cong. Anom. 25: 327-334.

Koresawa; M., Inaba, J. and Iwasaki, H. 1987. Fetal blood sampling by liver puncture. Acta Obst. Gynaec. Jpn. 39: 395-399.

Mibashan, R.S., Rodeck, C.H., Thumpston, J.K., Edwards, R.J., Singer, J.D., White, J.M. and Campbell, S. 1979. Plasma assay of fetal factors VIIIc and IX for prenatal diagnosis of haemophilia. Lancet I: 1309-1311.

Mikami, S., Nishino, M., Nishimura, T. and Fukui, H. 1987. RFLPs of factor IX gene in Japanese haemophilia $\mathrm{B}$ families and gene deletion in two high-responder-inhibitor patients. Jpn. J. Human Genet. 32: 21-31.

Mikami, S. 1988. Gene analysis in haemophilia A-Restriction fragment length polymorphism 
and molecular defects in the factor VIII gene. Acta Haematol. $J_{p n}$. 51: 1680-1688.

Nishino, M., Nishimura, T., Naka, H., Nakai, H., Miyata, S., Oku, K. and Mikami, S. 1986. Southern blot analysis of factor IX gene in hemophilia B. J. Nara Med. Ass. 37: 762-768.

Nishino, M., Nishimura, T., Naka, H., Mikami, S., Tokino, T. and Murotsu, T. 1987. Carrier detection in Japanese haemophilia A families using factor VIII gene probe (F8A) and genelinked St14-1 probe. Jpn. J. Human Genet. 32: 237-245.

Pecorara, M., Casarino, L., Mori, P.G., Morfini, M., Mancuso, G., Scrivano, A.M., Boeri, E., Molinari, A.C., Biasi, R.D., Ciavarella, N., Bencivelli, F., Ripa, T., 'Barbujani, G., Loi, A., Perseu, L., Cao, A. and Pirastu, M. 1987. Hemophilia A: Carrier detection and prenatal diagnosis by DNA analysis. Blood 70: 531-535.

Sampietro, M., Camerino, G., Romano, M., Cappellini, M.D., Fiorelli, G., Brambati, B., Guerneri, S., Ferrari, M., Travi, M., Krachmalnicoff, A. and Mannucci, P.M. 1987. Combined use of DNA probes in first-trimester prenatal diagnosis of hemophilia A. Thrombos. Haemostas. 58: $988-992$.

Tuddenham, E.G.D., Goldman, E., McGraw, A., and Kernoff, P.B.A. 1987. Haemophilia A: carrier detection and prenatal diagnosis by linkage analysis using DNA polymorphism. $J$. Clin. Pathol. 40: 971-977.

Williamson, R.E., Eskdale, J., Coleman, D.V., Niazi, M., Loeffler, F.E. and Modell, B.M. 1981. Direct gene analysis of chorionic villi: A possible technique for first-trimester antenatal diagnosis of haemoglobinopathies. Lancet II: 1125-1127.

Winter, R.M., Harper, K., Goldrnan, E., Mibashan, R.S., Warren, R.C., Rodeck, C.H., Penketh, R.J.A., Ward, R.H.T., Hardisty, R.M. and Pembrey, M.E. 1985. First trimester prenatal diagnosis and detection of carriers of haemophilia A using the linked DNA probe DX13. $B r$. Med. J. 291: 765-769.

Yoshioka, A., Peake, I.R., Furlong, B.L., Furlong, R.A., Giddings, J.C. and Bloom, A.L. 1983. The interaction between factor VIII clotting antigen (VIIICAg) and phospholipid. Br. J. Haematol. 55 : 27--36. 